\title{
Editorial: Observed and Predicted Changes in Climate in the Andes Cordillera
}

\author{
Mariano H. Masiokas ${ }^{1 *}$, Brian H. Luckman ${ }^{2}$, Mathias Vuille ${ }^{3}$, Ricardo Villalba ${ }^{1}$ and \\ Germán Poveda ${ }^{4}$ \\ ${ }^{1}$ Instituto Argentino de Nivología, Glaciología y Ciencias Ambientales, CCT CONICET Mendoza, Mendoza, Argentina, \\ ${ }^{2}$ Department of Geography, University of Western Ontario, London, ON, Canada, ${ }^{3}$ Department of Atmospheric and \\ Environmental Sciences, University at Albany, State University of New York, Albany, NY, United States, ${ }^{4}$ Department of \\ Geosciences and Environment, National University of Colombia at Medellin, Medellin, Colombia
}

Keywords: climate change, Southern Andes, Tropical Andes, instrumental records, climate models

\section{Editorial on the Research Topic}

\section{Observed and Predicted Changes in Climate in the Andes Cordillera}

\section{OPEN ACCESS}

Edited and reviewed by: Yuqing Wang,

University of Hawaii at Manoa, United States

${ }^{*}$ Correspondence:

Mariano H. Masiokas mmasiokas@mendoza-conicet.gob.ar

Specialty section: This article was submitted to Atmospheric Science, a section of the journal Frontiers in Environmental Science

Received: 05 August 2020

Accepted: 21 August 2020

Published: 25 September 2020

Citation:

Masiokas MH, Luckman BH, Vuille M, Villalba $R$ and Poveda G (2020)

Editorial: Observed and Predicted Changes in Climate in the Andes Cordillera.

Front. Environ. Sci. 8:591996. doi: 10.3389/fenvs.2020.591996
The Andes Cordillera forms a continuous high elevation range along the western margin of South America and constitutes a fundamental component in the environmental, cultural, and socio-economic fabric of the continent. Over its ca. 7,000 km-long extent, this mountain range contains an immense variety of climates and biomes and provides natural resources and ecosystem services to a population of almost 100 million people in Venezuela, Colombia, Ecuador, Peru, Bolivia, Chile, and Argentina.

Over the past decades various ecological, glaciological, and hydrological assessments have identified noticeable changes in vegetation dynamics, glacier cover and water availability in different sectors of the Andes. Although these findings can be at least partially associated with the occurrence of warmer and/or drier conditions across the Andes, additional, more detailed climatological assessments are needed to improve understanding of the complex patterns of climate change that have occurred in recent decades across this extensive mountain range. Given the predominant role of the Andean climate system on many socio-economic activities and on the most important hydrological and ecological processes in this region, further detailed studies are also needed to identify the most likely future climate scenarios for high elevation areas at different latitudes in the Andes. This Frontiers Research Topic compiles, in only a few studies, a great diversity of innovative meteorological, climatological, and glaciological analyses in different sectors of the Andes from Colombia to southern Chile and Argentina.

Bedoya-Soto et al. assessed the changes in the diurnal cycle of precipitation in the Andes of northwestern Colombia using local instrumental data. Interesting seasonal variations were identified associated with land surface-atmosphere interactions and regional circulation patterns, highlighting the importance of precipitation recycling and anabatic circulation across intra-Andean valleys. Vera et al. focused on the identification of the relative contribution of natural vs. anthropogenic forcings on the summer rainfall variability of the Altiplano region using reanalysis and climate model data. The negative rainfall anomalies observed in the Altiplano are associated with positive 200-hPa zonal winds over the region, and SST anomalies mainly in the tropical Pacific-Indian Oceans. The simulations indicate that natural variability can explain the observed year-to-year rainfall variability, but anthropogenic forcing is a necessary condition to explain the positive trends detected in the tropical SST and the regional zonal wind anomalies. The South 
American Monsoon can also exert a noticeable influence over the sign and magnitude of the precipitation changes observed in the Altiplano.

Ferrero and Villalba studied the decadal changes in precipitation in the subtropical Andes and Chaco regions of northwestern Argentina. Using a large dataset of instrumental records they show that precipitation amount and inter-annual variability have increased since the 1970s across the region. These changes seem to be associated with moisture sources from the Amazon basin and large-scale oceanic controls. The east-west contrasts in precipitation, cloud cover and cloud types across the Andes south of $20^{\circ} \mathrm{S}$ are evaluated by Viale et al. using daily instrumental and remote sensing (satellite) data. An impressive variety of climatic regimes and cloud patterns are described in this study, which clearly demonstrates the significant influence of the Andes on the climate of southwestern South America.

Barria et al. simulated the changes in the Equilibrium Line Altitude (ELA) of glaciers in the central Chilean Andes $\left(30^{\circ}\right.$ $38^{\circ}$ S) using radiosonde and instrumental precipitation data. As the ELA is strongly related to the annual mass balance of glaciers (higher ELA indicates more negative mass balances, and vice versa), it is an important parameter to evaluate their overall "health" over time. Since 1958, the simulated ELA for glaciers in central Chile has shown an overall long-term increase, with substantially higher values in the last two decades. These changes seem to be partly associated with warmer conditions across the region, but especially with the marked reduction in winter precipitation that has affected this region since 2010. Bravo et al. used direct measurements and modeled data to assess the main patterns of snow accumulation across the North and South Patagonian Icefields. Marked contrasts were found between the east and west margins of the icefields, especially in the autumn season. In some cases, positive trends in precipitation were observed in glaciers with relatively stable front positions, suggesting that these precipitation changes may have attenuated the overall pattern of ice mass loss evident across the region.
This small sample of studies illustrates the great variety and high quality of studies that are currently being conducted across the Andes. Interestingly, the studies of this Research Topic are strongly related to other ongoing initiatives intended to improve the current understanding of Andean hydro-climates and other related issues. The more recent Frontiers Research Topic entitled "Connecting Mountain Hydroclimate Through the American Cordilleras" has also compiled a very interesting set of studies that complement the findings of the papers discussed above. In particular, this Research Topic compiled several studies developed under the umbrella of the ANDEX ${ }^{1}$ program, a prospective Regional Hydroclimate Project (RHP) of the GEWEX ${ }^{2}$ Hydroclimatology Panel (GHP). The results and findings of all these new programs and studies have numerous applications at multiple levels. These include, but are not limited to, their use in policy decisions for local and regional sustainable development strategies, the management, and conservation of natural resources, the dissemination of important concepts and results to the general public, and the promotion of future related scientific research in this vast and diverse mountainous region.

\section{AUTHOR CONTRIBUTIONS}

MM wrote the first draft. All authors contributed with the revision and final version of this editorial.

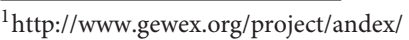

${ }^{2}$ http://www.gewex.org/
}

Conflict of Interest: The authors declare that the research was conducted in the absence of any commercial or financial relationships that could be construed as a potential conflict of interest.

Copyright (C) 2020 Masiokas, Luckman, Vuille, Villalba and Poveda. This is an openaccess article distributed under the terms of the Creative Commons Attribution License (CC BY). The use, distribution or reproduction in other forums is permitted, provided the original author(s) and the copyright owner(s) are credited and that the original publication in this journal is cited, in accordance with accepted academic practice. No use, distribution or reproduction is permitted which does not comply with these terms. 